Daniel Weidner · Sigrid Weigel (Hrsg.)

Benjamin-Studien 2 

Daniel Weidner · Sigrid Weigel (Hrsg.)

Benjamin-Studien 2

Wilhelm Fink 
Bibliografische Information der Deutschen Nationalbibliothek

Die Deutsche Nationalbibliothek verzeichnet diese Publikation in der Deutschen Nationalbibliografie; detaillierte bibliografische Daten sind im Internet über http://dnb.d-nb.de abrufbar.

Alle Rechte, auch die des auszugsweisen Nachdrucks, der fotomechanischen Wiedergabe und der Übersetzung, vorbehalten. Dies betrifft auch die Vervielfältigung und Übertragung einzelner Textabschnitte, Zeichnungen oder Bilder durch alle Verfahren wie Speicherung und Übertragung auf Papier, Transparente, Filme, Bänder, Platten und andere Medien, soweit es nicht $\$ \$ 53$ und 54 UrhG ausdrücklich gestatten.

(C) 2011 Wilhelm Fink Verlag, München

(Wilhelm Fink GmbH \& Co. Verlags-KG, Jühenplatz 1, D-33098 Paderborn)

Internet: www.fink.de

Die Drucklegung dieses Werkes wurde unterstützt mit den Mitteln des Bundesministeriums für Bildung und Forschung unter dem Förderkennzeichen 1UG0712.

Lektorat: Bettina Moll, Berlin

Satz: Tilo Lothar Rölleke, Berlin

Einbandgestaltung: Evelyn Ziegler, München

Printed in Germany

Herstellung: Ferdinand Schöningh GmbH \& Co. KG, Paderborn

ISBN 978-3-7705-5071-5 


\title{
NitZan Lebovic
}

\section{Benjamin's Nihilism Rhythm and Political Stasis}

\begin{abstract}
Walter Benjamin's best-known comment regarding nihilism - „to strive for such a passing away [for nature is messianic by reason of its eternal and total passing away] [...] is the task of world politics, whose method must be called nihilism" (SW III, 306) - occurs at the conclusion of his "Theological-Political Fragment" (1920-1921). ${ }^{1}$ In this pithy fragment Benjamin challenged the distinction between the political and the theological by pointing out the necessary relation - even codependence - of historical time and messianic time, the secular and the redemptive. The focus is the temporal dimension that dictates one's "rhythm of life, " on the one hand, and politics - its formative power - on the other. Benjamin's translation of such abstract principles into different systems - the secular and the religious, the abstract and the particular, the collective and the individual - have confused scholars for many years. The result was often a misreading of Benjamin's last sentence, connecting politics to nihilism and identifying the maker with his method.

In order to reverse such readings, this chapter moves in four consecutive stages. I begin with the "temporal-rhythmic " principle, relating it to Benjamin's notion of Nihilism as a method. Second, I consider the specific meanings of "Nihilism" during the 19th and early 20th centuries, which I identify with the idea of a temporal stasis. Third, I track down Benjamin's uses of Nihilism and demonstrate that they reflect a certain methodological approach rather than a solution to a problem. Finally, commenting directly on contemporary interpreters of Benjamin who see him as a "nihilist" or an "anarchist, "I show that Benjamin focused on the temporal and critical dimensions in order to overcome nihilism and stasis.
\end{abstract}

\section{The Temporal-Rhythmic Principle}

The Theological-Political Fragment separates and reconnects the secular and the religious. The heart of the secular world, Benjamin pointed out, is absorbed in an obsessive search for happiness, which implies a certain closeness to the kingdom

1 "Diese zu erstreben, auch für diejenigen Stufen des Menschen, welche Natur sind, ist die Aufgabe der Weltpolitik, deren Methode Nihilismus zu heissen hat" (GS II, 204). 
of heaven. Herein lies a substantial paradox: the system that is determined to get us there, nihilism, is also where we lose our way. By seeking happiness through suffering we are pursuing the course identified by Nietzsche as "suicidal. " If politics is working through nihilism as a method, it implies also that disaster and suffering mediate between the origin of action and its goal. Happiness stands here for "a totality and world experience " that is grounded in repetitive temporal order, a »rhythm«: Right before the final sentence of the fragment Benjamin identifies two rhythmic principles; the messianic and the natural, both translated into their supposed opposite, the messianic into the secular and the natural into an "eternal" and "total" dimensions (SW III, 306). In short, it is rhythm that forms the ontological principle of all systems, the heartbeat of the natural eternal recurrence and simultaneously the individual's rhythm of "total passing away«:

The spiritual restitutio in integrum [...] corresponds to a worldly restitution that leads to an eternity of downfall, and the rhythm of this eternally transient worldly existence, transient in its totality, in its spatial but also in its temporal totality, the rhythm of messianic nature, is happiness. For nature is messianic by reason of its eternal and total passing away. (305)

The closure of the fragment shifts gears into the rhythm of politics; striving for the temporal order of eternal recurrence is the task of world politics, and "its method «. In short, in the secular world only a nihilistic-messianic-repetitive rhythm can supply us with what we need, if not in politics, then in philosophy and the arts. It is worth noting that Benjamin both distances himself from the need to work under these conditions - perhaps in contrast to politicians or political philosophers - and accepts them as the contemporary conditions of existence. In other words, to identify Benjamin with his nihilistic-messianic analysis is to identify his position with his toolkit. Identifying him with his observation regarding messianism is missing the whole point of an ontology of temporal or rhythmic order.

But what is this nihilism? How could it help us understanding Benjamin and his view of politics? The last statement of the fragment provokes, I believe, a series of questions concerning politics and the limits of political critique. The questions emerge from an act of exposure that is immediately placed - actualized - in an antinomian relation. A nihilistic method must adopt a temporality separated from "the task of politics, " its "passing away," erasing progressive temporality in favor of a catastrophic and suicidal collapse, or its living potential in actuality.

If Benjamin emphasizes actuality, it is, as Sigrid Weigel pointed out in Body-and Image-Space, "to expel moral metaphors from politics and to discover in the sphere

2 "Active Nihilism, in Nietzsche's view, is more desirable because it brings itself and the Christian world to a more expeditious end" (Michael Allen Gillespie: Nibilism Before Nietzsche, Chicago [University of Chicago Press] 1995, p. 180). 
of the political action a total, hundred percent image-space [Bildraum]. $\aleph^{3}$ In other words, at the heart of the political, according to Benjamin, there is a rhythm that is devoid of politics or rather, that is repetitive, free and "ungovernable. " ${ }^{4}$ It is worth noting that nihilism serves here as a way to radicalize the issue before the ungovernable is contained or the standoff reverts to respectful dialogue.

Now, before returning to Benjamin's view of nihilism and the eternal recurrence, let me say a few words about the tight relationship between Nihilism and a certain temporal order.

\section{Nihilism and Stasis in Europe}

Nihilism, according to Friedrich Heinrich Jacobi's 1799 attack on Johann Gottlieb Fichte, is the product of a philosophy of "mere appearances and thus of nothing. " Fichte did speak of a philosophy of not-knowing, but he distinguished between two forms of nothing: the philosophy that claims to know everything but reduces everything to nothing, and the philosophy of not-knowing which the German Idealists identified as a chimera, a demon or a monster, a Zäsur, an illogical duality beyond one's belief in destruction. "In their opinion every decision was left up to individual inclination or caprice. « Fichte's conclusion that the Enlightenment notion of reason was inadequate to grasp the infinite essence of the self, and that a more radical tool was needed, guided him towards an infinite longing which Jacobi recognized as a nihilist notion: "Absolute liberation and reconciliation floats like a vision before us drawing us onward, but it is never attained. [...] [It is] a drive toward something unknown which reveals itself through need, discomfort, and a void. ${ }^{7}$ This radical freedom, Bernard Willms showed in his interpretation of Fichte, ends with "the war of all against all. ${ }^{8}$ Michael Allen Gillespie identifies as the starting point of nihilism "Fichte's rejection of the Enlightenment notion of reason in favor of an absolute subjectivism that attempts to derive all reason from the infinite will

3 Sigrid Weigel: Re-reading Walter Benjamin, trans. Georgina Paul, London (Routledge) 1996, p. 7.

4 Giorgio Agamben: What Is an Apparatus? And Other Essays, trans. David Kishik/Stefan Pedatella, Stanford (Stanford University Press) 2009, p. 24.

5 Friedrich Heinrich Jacobi: Werke 3:29, quoted and translated in: Gillespie: Nibilism before Nietzsche (note 2), p. 66.

6 Ibid.

7 Ibid., p. 90.

8 Bernard Willms: Die totale Freiheit. Fichtes politische Philosophie, Köln (Westdeutscher Verlag) 1967, p. 110, quoted in: Gillespie (note 2), p. 94. 
of the absolute I. [...] [This] leads, as Jacobi realized, to the death of God and the deification of man. ${ }^{9}$ Karl Löwith identified this moment as the birth of the internal division of the critical self: "Of course Europe had already advanced a critique of itself, one more radical and open, more serious and penetrating, than the foreign critique. $\aleph^{10}$

Early-19th-century nihilism shaped a critical terrain in which absolute subjectivity threatened the collective decorum created by and for the politics of restoration. A drive to the unknown was led by the sense of the absolute "I" that was nonetheless signified by a system of universal representation. Such deep changes troubled thinkers like Jacobi, who correctly identified the hermeneutic "salto mortale" performed by Lessing and Fichte, warning that it might end with a catastrophic fall from the political trapeze. ${ }^{11}$

"My most secret thought, " wrote Karl Löwith, quoting Metternich, after the Congress of Vienna, "is that the old Europe is at the beginning of its end. $\aleph^{12}$ Shortly before, the young Hegelians had turned to negation as a means to generating a reevaluation; this led to a version of "destructive nihilism" that was "unable to accomplish anything of value and [was] content with social position and a fading renown. ${ }^{13}$ The result of the monarchist attempt to restore a politics of suspense after the Congress of Vienna and again after the Spring of Nations in 1848 led many thinkers across Europe to a radical critique of politics and a growing attraction to nihlism. As this trend moved eastward it was radicalized and actualized: "The Russian debate over nihilism is thus an extension of the German controversy [...] [but] Russian nihilism is often identified with the spasm of negation that shook the country from 1858 to 1863 [...] [which] marks the moment when nihilism passed from the realm of ideas into actuality. ${ }^{14}$ Löwith labeled the German and the Russian forms of nihilism that he conceptualized "European, « though this form of Europeanism was grounded in a series of separations and violent outbursts, concluding with the most violent of all, civil war. Citing Jacob Burckhart, he predicted that "something like the age of the Caesars in Rome is impending for Europe, an age on the horizon of which there lie great civil wars. ${ }^{15}$

9 Ibid., p. 99.

10 Karl Löwith: Martin Heidegger and European Nihilism, trans. Gary Steiner, New York (Columbia University Press) 1995, p. 176.

11 Friedrich Heinrich Jacobi: Über die Lehre des Spinoza in Briefen an den Herrn Moses Mendelssohn, Breslau (Löwe) 1785, p. 17.

12 Ibid., p. 184.

13 Gillespie: Nihilism before Nietzsche (note 2), p. 131.

14 Ibid., p. 139.

15 Löwith: Heidegger and European Nihilism (note 10), p. 185. 
The beginning of the end, the looming time of civil war, is known as stasis, a term also used for the suicidal body's suspension of its own functions. ${ }^{16}$ Stasis marks the demise of the old civilization and the end of philosophy, declared in the beginning of the 19th century by the Left Hegelian Bruno Bauer and repeated in Löwith's characterization of nihilism. ${ }^{17}$ The modern state, secular politics, and nihilistic method all led to stasis as the secret heart of modern politics. It was the political freedom of democracy, as Burckhardt identified it, that would drive the »boundless augmentation of power. [...] An unbounded feel for business goes hand in hand with the feel for power, the state becomes a large-scale manufacturer and a military despotism. ${ }^{18}$

At the end of the 19th century, a Bismarckian Germany proved to move simultaneously in two opposing directions, playing both games of democratization and military despotism into a politics of suspense. This was the situation Nietzsche experienced with the rise of a united Germany under the control of Prussian bureaucracy. As Roland Duhmal showed, this would lead to a circular notion of nihilism and to seeing it was an event [Geschehen], not a position [Zustand]. (19 $^{19}$ Action without orientation: the rhythm of nihilism turned out to be more important than its impact. The nihilist movement Gillespie describes as "essentially Promethean « was presented by Ivan Turgenev and Alexander Herzen as a destructive drive without a purpose, the deadly rhythm of a body that keeps attacking its own cells. ${ }^{20}$ The theory presents an alternative logic that resists the very notion of a governing apparatus: "Nihilism is logic without structure, it is science without dogmas, it is unconditional submission to experience and the resigned acceptance of all consequences. [...] Nihilism does not transform something into nothing, but shows that nothing which has been taken from something is an optical illusion. $\aleph^{21}$

In other words, Nihilism as a (repetitive) rhythm or a (an empty) method created the new structure of power and of world politics. According to Dirk Solies, Nietzsche presented nihilism in the 1880 s as the transformation of life into

16 See the different meanings of stasis in the articles, available at: http://en.wikipedia.org/wiki/ Stasis_(political_history) and http://en.wikipedia.org/wiki/Stasis_(medicine), accessed March 31, 2011.

17 Löwith: Heidegger and European Nihilism (note 10), p. 187.

18 Ibid., p. 185.

19 Roland Duhmal: Die Decke auf den Kopf. Versuch einer Deutung des Nihilismus, Würzburg (Königshausen \& Neumann) 2006, p. 12.

20 Gillespie: Nihilism before Nietzsche (note 2), p. 139.

21 Alexander Herzen: My Past and Thoughts. The Memoirs of Alexander Herzen, trans. Constance Garnett, New York (Knopf) 1973, p. 642, quoted in: ibid., p. 139. 
power, "the power which determines the essence of empirical reality. « ${ }^{22}$ Löwith, and Benjamin following him, identified nihilism with the will to power and the principle of eternal recurrence. This idea, appearing early in Benjamin's philosophy, was made explicit in the Arcades Project (1940). In it, Benjamin hypothesized that Nietzsche's visit to Italy gave birth to the concept of eternal recurrence, a rhythm without a purpose or a structure. It was in Rapallo, Benjamin tells us, in the winter of 1882-1883, that the thinker conceived of Thus Spoke Zarathust$r a$, leaving behind an earlier "philosophy of the dawn" and inaugurating a "philosophy of the noontide«. ${ }^{23}$ Benjamin followed Löwith's analysis very closely, and he felt that Zarathustra marked the shift to a philosophy of the eternal return. ${ }^{24}$ In the notebooks he filled from 1885 to 1886 , Nietzsche briefly defined nihilism as "the radical rejection of value, meaning, desirability. ${ }^{25}$ It was an error, he emphasized, to ascribe nihilism to "social hardship, or physiological degeneration or even corruption. « $^{26}$

In this sense, Nietzsche affirmed that nihilism belonged to a certain geography of religion and culture, typically marked as Christian and European. One could call it part of the backlash against the idea that God is truth, a movement that declared, "Everything is false." Jacobi's critique of Fichte as a »Spinozist, « atheist, and pantheist, resides at the heart of the debate over science. For Jacobi, giving up on a particular theist position forced a certain lack of criteria and values. ${ }^{27}$ In political terms, nihilism might be used to attack principles with »the tinge of mediocrity, meanness, insincerity, etc. Nationalism, anarchism, etc. Punishment. Lack of redeeming class and man, the justifiers. ${ }^{28}$ It could influence the civil war of all: a critical culture turning into its own veil of power and death, propelled by its own active, repetitive, homogenous, empty sense of time. At such a moment, no movement is possible, a vast internal chasm gapes, and an armed body-politic rises under the bloody horizon of the natural-catastrophic or the supernatural redemptive. ${ }^{29}$

22 Dirk Solies: „Die Naturwissenschaften des 19. Jahrhunderts und der Lebensbegriff des Zarathustra, «in: Nietzscheforschung. Jahrbuch der Nietzsche-Gesellschaft 9, ed. by Volker Gerhardt/ Renate Reschke, Berlin (Akademie Verlag) 2002, p. 281.

23 Walter Benjamin: The Arcades Project, trans. Howard Eiland/Kevin McLaughin, Cambridge et. al. (The Belknap Press of Harvard University Press) 1999, p. 360.

24 "Against the background of his sphilosophy of the noontide - the doctrine of eternal recurrence - Nietzsche defines the earlier stages of his thinking as philosophy of the dawn and philosophy of the morning" (ibid.).

25 Friedrich Nietzsche: Writings from the Late Notebooks, trans. Kate Sturge, ed. by Rüdiger Bittner, Cambridge (Cambridge University Press) 2003, p. 83.

26 Ibid.

27 Ibid.

28 Ibid., p. 84. All emphases in the original.

29 In the essay on Kafka he wrote in 1934, Benjamin rejected both interpretations even as he applied them (cf. "Franz Kafka,« in: SW II, 806). 


\section{Benjamin's »Nihilism«?}

In general, scholars have usually addressed either Benjamin's anarchist sympathies, his messianic/catastrophic notion of time, his attraction to historical materialism, or his emphasis on revolutions, relying on Critique of Violence (1921), the "Theological-Political Fragment," probably from the early 1920s, Moscow Diary (1928), "Destructive Character" (1931), and his analysis of the French Revolution in the Theses on the Philosophy of History (1940) or the Arcades Project (1940). Even from this short list of works, it is clear that nihilism was a consistent point of reference, one recognized by his different critics and admirers, no matter their approach to his work. But much like those who studied his messianism, analysts of Benjamin's nihilism looked at it not as a form of hermeneutics, a shape or a horizon of expectations that he used, but as his actual aim. In the following section I intend to analyze short segments from Benjamin's work about nihilism, and then return to his interpreters.

The works mentioned in the previous paragraph share a certain tone, are densely written, and refer to a notion of totality as a critical horizon with hermeneutic value. Benjamin's own antinomian method created a sophisticated tactic, walking a very thin line: »Benjamin's nihilism may be read as an enduring part of his temperament, or less psychologically, as a part of a set of persistent metaphorical preferences; undoubtedly it was both. ${ }^{30}$

A close reading picks out not only development and change in Benjamin's thinking but telling contrasts. The only possible unity resides at a hypothetical radical horizon. Let us begin with the most obvious and best discussed example, the very last sentence of "The Destructive Character." This places his notion of the will to destruction far from if not in opposition to his view of nihilism. Benjamin concludes his reflections with the following observation: "The destructive character lives from the feeling not that life is worth living, but that suicide is not worth the trouble." (SW II, 542) In other words, if actual suicide is prevented it is because the paralyzing rhythmus of the everyday overcomes self-destructiveness. The method overcame both the goal and the original intention.

In his »Present Social Situation of the French Writer, from the late 1920s, Benjamin characterized Maurice Barrès as a "romantic nihilist, " one who believed what severything amounts to the same thing, with the exception of the excitement [...] for those who have managed to adopt the right point of view, there are no great events but only magnificent spectaclesı." (SW II, 745) If modern Romantic nihilism requires such enthusiasm, Benjamin's destructive character was not up to the mark. The romantic nihilist, a modern type, is an enthusiast,

30 John McCole: Walter Benjamin and the Antinomies of Tradition, Ithaca (Cornell University Press) 1993, p. 167. 
but he or she conformed to existing temporal models called progress and idealism. "The more thoroughly we become acquainted with his [i.e., the modern nihilist's] ideas, "Benjamin wrote, "the more closely they seem to be related to the doctrines which the present age has everywhere brought forth. They consist of the same basic nihilistic outlook, the same set of idealistic gestures, and the same conformism that result from the synthesis of nihilism and idealism" (ibid.). It is somewhat shocking to realize that for Benjamin nihilism intersected with idealism and conformism, and that he was searching for a tool that would allow him to overcome nihilism, which he identified with unconscious mental oppression in the context of modernity and a failed state apparatus.

His interpretation of Nietzsche in The Origin of German Tragic Drama (1928) demonstrates how Benjamin uses an alternative temporal order as a tool to reframe the distinctions between private and public. Shortly before encountering Löwith's Nietzsches Philosophie der ewigen Wiederkehr des Gleichen und Jacob Burckhardt (1934) which had such an impact on his Arcades Project, Benjamin looked at Nietzsche's nihilism through Franz Rosenzweig's eyes, relying on »life in its extreme sense, that is to say where it fulfils itself in death, the abode of danger as such. $\aleph^{31} \mathrm{He}$ emphasized that this was an attempt to overcome "The nihilism lodged in the depths of the artistic philosophy of Bayreuth, « explaining that "Nietzsche argues that one must ralways keep in mind that the public at an Attic tragedy found itself in the chorus of the orchestra [...] a great sublime chorus of dancing and singing satyrs. ${ }^{32}$ So he concluded that "The truth content of this totality, which is never encountered in the abstracted lesson, least of all the moral lesson, but only in the critical elaboration of the work itself, includes moral warnings only in the most indirect form. ${ }^{33}$ Indirect, perhaps, but nonetheless instructive and crucial.

The equivalent sentence in the Arcades Project is a quotation in which Löwith commented on Nietzsche's nihilism. It is identified with "the instinct for selfdestruction, the will into nothingness, " and Löwith spoke of nihilism as a "symptom" of those who "destroy in order to be destroyed. "34 $^{34}$ Benjamin's fragment continues the same emphasis on nihilism as an active deed of self-destruction. The fragment reads: „On suicide as signature of modernity. `One cannot sufficiently condemn Christianity for having devalued the value of such a great purifying

31 Walter Benjamin: The Origin of German Tragic Drama, trans. John Osborne, New York (Verso) 1998, p. 105.

32 Ibid., p. 103.

33 Ibid., p. 105.

34 Friedrich Nietzsche: „Notebook 5, summer 1886-autumn 1887«, in: id.: Writings from the Late Notebooks (note 25), p. 120. 
nihilistic movement, as was perhaps already being formed, ... through continual deterrence from the deed of nihilism, which is suicide. ${ }^{35}$

During the late 1920s and the early 1930s, Benjamin's attempt to overcome nihilism, especially in its political form, grew more determined. Interestingly, he wanted to pierce nihilism through its heart, exploring its potential for a radical hermeneutics in order to overcome it.

\section{Nihilistic Reviews}

Within the large body of literature dedicated to Benjamin's political radicalism are many references to nihilism. Irving Wohlfarth wrote in 1978, "A strain of revolutionary nihilism is inseparable from Benjamin's writings. ${ }^{36}$ The year after, Ansgar Hillach presented nihilism as a general framework for Benjamin's historical thought, describing a regression that warises from the obvious loss of the possibility of ideological interpretation in the face of mechanization and its compensation. ${ }^{37}$ Two years later, Richard Wolin divided Benjamin's work into three periods, noting that "the 'Nihilism' of his former days is never wholly relinquished. ${ }^{38}$ Michael Jennings wrote in 1987 of his "avowed nihilism, « rejecting the idea that his messianism made him an optimist. ${ }^{39}$ More recently, Uwe Steiner and Werner Hamacher, among others, have included reflections on the issue in a discussion of Benjamin's "political nihilism, " which Steiner develops around Benjamin's interest in Ernst Bloch's work, and Werner Hamacher has called »methodical nihilism « Benjamin's »complement of the operational, methodical 'nothing of [Hermann] Cohen's theory of judgment. « ${ }^{40}$

In Dialectical Images, Jennings looked at the period from 1924 to 1940, noting, "The reading of [Lukacs'] History and Class Consciousness revealed to Benjamin that this early thought, and especially his dualism and nihilism, could be translated directly into political categories. ${ }^{41} \mathrm{He}$ began his review of what he called »Benjamin's subversiveness and revolutionary fervor, his commitment to nihilism

35 Benjamin is quoting from: Karl Löwith: Nietzsches Philosophie der Ewigen Wiederkehr des Gleichen, 1935 (Die Runde) Berlin, p. 108, (cf. Arcades Project [note 23] p. 369 f.).

36 Irving Wohlfarth: »No-Man's-Land. On Walter Benjamin's 'Destructive Character», Diacritics 8 (1978) 2, p. 56.

37 Ansgar Hillach: "The Aestehtics of Politics: Walter Benjamin's iTheories of German Fascism`« New German Critique 17 (1979), p. 103.

38 Richard Wolin: „From Messianism to Materialism. The Later Aesthetics of Walter Benjamin, « New German Critique 22 (1981), p. 95.

39 Michael W. Jennings: Dialectical Images. Walter Benjamin's Theory of Literary Criticism, Ithaca/N.Y. (University of Cornell Press) 1987, p. 60.

40 Werner Hamacher: "Guilt History. Benjamin’s Sketch `Capitalism Religion`, Diacritics 32 (2002) 3-4, p. 101.

41 Ibid., p. 72. 
and fragmentation" with a stark critique of Wolin's »straightforward advocacy of Adorno at Benjamin's expense, « accusing Wolin of producing "a traditionally conservative Benjamin. «2 Rather than follow Jürgen Habermas' and Gershom Scholem's reading of Benjamin as a "conservative revolutionary rhetoric, "Jennings linked the conclusion to the "Political-Theological Fragment" to later work. As a result, he rejected Scholem's dating of the fragment to the late 1910s, insisting that the

"Theological-Political Fragment« is, in its clarity, one of the keys to Benjamin's philosophy of history. [...] [Adorno and Scholem's dating] is a convenient resolution, since the placement of a forthright nihilism within the context of Benjamin's early, »metaphysical« work to a certain extent naturalizes and disarms it. I tend to agree with Adorno's initial conjecture, however. As a text of the early twenties, it would stand in rather severe isolation as the only such meditation from the period. In the later 1930s, however, it would figure as a key link in what would otherwise remain the disjunctive world of Das Passagen-Werk, the Baudelaire studies, and especially the "Theses on the Philosophy of History. « ${ }^{43}$

The question went far beyond a date, since it had implications for the value of Benjamin's political involvement and the legacy of his radical critique. What, Jennings asked, was the place of actuality in and around Benjamin's writing? Could his critique be regarded as nihilistic or revolutionary? (Yes, said Jennings; Maybe, said Wohlfarth; Absolutely not, said Wolin.) Was it limited to its time, or could it be used as a gauge of critical methods and concepts for our time?

In a recent essay, "Nihilismus kontra Nihilismus, zur Aktualität von Walter Benjamin Weltpolitik, " a contribution to his long lasting interest in the topic, Wohlfarth took on Habermas' critique of actuality, Weigel's close reading of Benjamin's image-work and Jennings' critique, but from a very different perspective. Wohlfarth argued that Benjamin's nihilism should be considered alongside his political theology. Considering all this in terms of current affairs, he turned Benjamin against Jacques Derrida and Giorgio Agamben:

The only meaningful European philosophy [...] tries to think further this political inheritance $[. .$.$] in contrast, I would like to state the following thesis:$ Benjamin's 'political theology has more to it than the perverse play of the present which controls the world stage, but is a powerful antidote against it. It is no coincidence that it carries the name of its opponent: Nihilism. ${ }^{44}$

42 Jennings: Dialectical Images (note 39), p. 6.

43 Ibid., p. 59.

44 Irving Wohlfarth: "Nihilismus kontra Nihilismus. Walter Benjamins ,Weltpolitik aus heutiger Sicht, « in: Theologie und Politik. Walter Benjamin und ein Paradigma der Moderne, ed. by Bernd Witte/Mauro Ponzi, Berlin (Erich Schmidt Verlag) 2005, p. 113; trans. L. N. 
Unlike Weigel and Jennings, Wohlfarth ignored Benjamin's attempt to distance the struggle from the actual Weltpolitik. One should recall that in the fragment it is the method of the political rival that matters rather than his identity. One does not have to swear an oath of fidelity to current politics or its enemy, nihilism, in order to use it in politics. On the contrary: as Benjamin argued in his introduction to the Trauerspiel book (1928), "Method is a digression $"{ }^{45}$. Now, if we bring the two statements concerning method together, we end with nihilism as the digression from politics, a wholly positive one, for the sake of a better politics-to-come.

In other words, Wohlfarth reads nihilism correctly as the enemy of metaphysics, but then moves to identify it wrongly with theology, that is, with a stable form of identity: "Benjamin distances himself from Nietzsche in that his nihilism, even if anti-metaphysical, is originated in theology. The Dionysian and Messianic are closely tied in the Theological-Political Fragment and at the end of the Surrealism essay. " ${ }^{46}$ Wohlfarth misses Benjamin’s dynamic use of nihilism as a hermeneutic tool, treating it as an entity in isolation, or rather, as an anchor for political theology. Reading Benjamin's dynamic use of temporality as secondary to his messianic politics is a typical approach to those interpreters who focus on political theology as a solution to contemporary problems: Benjamin's spolitical theology is "a model of messianism that reconceives the political theological relationship between the divine and the creaturely. ${ }^{47}$

So what is this nihilistic method, the digression from politics? In his "True Politician, "Uwe Steiner presented the concluding sentence of the "TheologicalPolitical Fragment « as the result of the tension between the secular order and the metaphysical values on which politics rely. Steiner's own conclusion is: »Wherever politics sets goals, it must restrict them to the order of the profane. And because politics is restricted to the profane, its aims are in the final analysis vain. ${ }^{48} \mathrm{Just}$ as Bloch and Lukacs suggested in 1924 and 1925: "At the apex of modernity [...] the true politician [has] the features of an archaic priest. " ${ }^{49}$ Nevertheless, he is the opposite of anything messianic, wearing overalls rather than robes. As the same

45 Benjamin: The Origin of German Tragic Drama (note 31), S. 28.

46 Wohlfarth: "Nihilismus kontra Nihilismus» (note 44), p. 113, trans. L. N.

47 Kenneth Reinhard's crisp and provocative reading is one, highly interesting, example for this "political theological" school that has recently depicted Walter Benjamin in general, and this fragment in particular, as its mode of operation. Giorgio Agamben, Eric Santner, Irving Wohlfarth and Mladen Dolar could be seen as other scholars operating within this hermeneutic context. See Kenneth Reinhard: "Paul and the Political Theology of the Neighbor" (January 17, 2011; available at: http://ebookbrowse.com/paul-political-theology-neighbordoc-d50171724, accessed March 31, 2011).

48 Uwe Steiner: "The True Politician. Walter Benjamin’s Concept of the Political,« New German Critique 83 (2001), p. 49.

49 Ibid., p. 67. 
authors showed: "The organization was the form of mediation between theory and practice. ${ }^{50}$ This was why Benjamin expected their work to "reinforce his political nihilism [...] confronting the text with his own fundamental belief in the limitation of the political to the order of the profane. ${ }^{51}$ In short, political nihilism should be read as a negative threshold placed as a digression or a suspense of action, rather than as a tool to fix or confirm the right path of action. Such a limit could be introduced only after the political accepts the theological interruption residing at its heart, lying close to the origin of words and concepts.

The fruits of such previous discussions may be enumerated:

1. Benjamin's ideas tended to link different fields and perspectives. For instance, it is impossible to separate Benjamin's understanding of politics from his understanding of history, his understanding of temporality, or his analysis of mechanisms and methodologies. Conscious of the blinding light stemming from general categories and principle concepts, Benjamin was always looking askance. His was a sort of night vision, relying on the corners of his eyes to pick out barely visible stars.

2. To understand Benjamin's political analysis one must acknowledge the impact of a post-Nietzschean cultural crisis during the mid-1920s, as well as his views on linear time and eternal recurrence, the human temporal order (the opposite of historicization), and the cosmological perspective..$^{52}$

3. Benjamin's nihilism uses different forms of suspense, but always from a critical perspective: a suspension of any given movement between past and future, a suspension of the separation between normality and abnormality, a suspension of law (and its distinction from criminality), a suspension of the political and of the division between church and state, a suspension of given aesthetic forms and of intentionality, that is, the metaphysics of the will. The ever-growing Benjaminian literature tends to emphasize the utopian element of his thinking and to ignore its rejection of the future except insofar as it serves as a critical tool to observe the past. Few have noted that Benjamin himself never acknowledged the disjunction between catastrophe and the path out of it (here I see the Jewish element of his thought) - leading backwards, back to the ruins, instead of into a new utopia. The permanent state of emergency depends on the potentia of destruction, its threat - which allows the sovereign his freedom of action, his decisionism - and stands in stark opposition to its realization. The ruins are already there, in the past. So is the way out. Recognizing it forms a nihilist moment, assuming the death of intentionality, the lack of will, the expulsion of moral metaphors or the absence of redemption.

50 Ibid., p. 80 .

51 Ibid., p. 79.

52 Stéphane Mosès: Walter Benjamin and the Spirit of Modernity, Tel Aviv (Resling) 2003, p. 99-112. 


\section{Conclusion: Where Benjamin, Benjaminians, and Biopolitical Critique Fall Short}

In Benjamin, the suspense, as Wohlfarth argued, resides at the heart of the political: "Already in 1927 [Benjamin] considered the political state of free-floating suspension [GS IV, 486] with which Scholem was to reproach him. ${ }^{53}$ This floating suspension, the method of the political, was common to Benjamin and to the revolutionary suspense of time: "Benjamin conceives revolution as the leap that abruptly suspends it [i.e., natural history]. To the stoppage of time, the $>$ Messianic cessation of happening` [GS III, 263], corresponds the destructive expropriation of space. $" 14$

The suspension of action has little to do with the fusion of politics and religion Scholem presented in his sketches of an ideal Zionist state: "Marx sagt, die Revolutionen sind die Lokomotive der Weltgeschichte. Aber vielleicht ist dem gänzlich anders. Vielleicht sind die Revolutionen der Griff des in diesem Zuge reisenden Menschengeschlechts nach der Notbremse« (GS I, 1232). Mapping Benjamin's usage of the concept of revolution, Erdmut Wizisla reminded us that "Revolution war nicht die ultima ratio seines Denkens. [...] Revolution ist für ihn kein ausschliesslich politischer Ausdruck, sondern eine Kategorie, in der politisch-historischen Aktion. $"{ }^{55}$

Recent writers, including Agamben, have not always appreciated the distinction between the Schmittian cessation of the political - by the sovereign, whether a Paulinian ruler or a "simple« secular sovereign - and Benjamin's suspension of the political by the permanent sense of emergency itself. All too quickly, nihilism becomes a free-floating boundary between political praxis and political critique. We should recall Samuel Weber's cautionary words:

Benjamin, by contrast [to Schmitt], describes the task of the sovereign in the very terms that Schmitt rejects: The sovereign is charged with the task of excluding the state of exception [...] that which is already exterior, the Aus-nahmezustand, is to be exteriorized once again, aus-geschlossen, and this applies [...] to the state of exception as such, that is, as that which transcends the state in general [...] transcending transcendence. ${ }^{56}$

53 Wohlfarth: „No-Man's-Land « (note 36), p. 49.

54 Ibid., p. 58.

55 Erdmut Wizisla: „Revolution,« in: Michael Opitz/Edmut Wizisla (eds.): Benjamins Begriffe, vol. 2, Frankfurt a.M. (Suhrkamp) 2000, p. 665.

56 Samuel Weber: "Taking Exception to Decision. Walter Benjamin and Carl Schmitt, in: Enlightenments. Encounters between Critical Theory and Contemporary French Thought, ed. by Harry Kunneman/Hent de Vries, Kampen (Kok Pharos) 1993, p. 153. 
Nihilism, or a messianic/revolutionary Notbremse, must be read here as a provocative threshold. This is why Benjamin never left the humanist grounds of his education, and this is why his sense of actuality does not suit today's needs. This is acutely so for Israelis living in a permanent state of emergency. Where the political sphere has collapsed, nihilism retreats to the form of stasis, where no leap is ever possible, because there is no sovereign with the power to set matters back on a constitutional footing. Happiness, peace, reason - these are terms that provoke a mocking smile. What we are left with is the method, or rather, a regressing method without an end. Benjamin's nihilism is not the opposite of happiness, but the opposite of a naïve and ignorant secular order and the opposite of any affirmative politics, religious or profane. Current nihilism, when the political has collapsed, moves beyond Benjamin: not only is there the temporary suspense of orientation, of a goal, but the absolute stasis without an end, destroying all traces of the political - and the temporal with it. "For swar consisteth not in battle only, « wrote Thomas Hobbes, »or the act of fighting; but in a tract of time, wherein the will to contend by battle is sufficiently known: and therefore the notion of 'time is to be considered in the nature of war, as it is in the nature of weather. ${ }^{57}$ 